\section{Birlesik Dünya Arastırma New Trends and Issues BD-CENTER Proceedings on Humanities and Innovasyon ve Yayıneılık Merkezi \\ Social Sciences}

Volume 7, Issue 3, (2020) 252-261

\title{
Examination of toy preferences - play skills and aggression tendencies of 60-72-month-old children
}

Gizem Gursoy Yilmaz*, Psychological Counselling Center, Vesta, Cevizli, Hukukcular Towers B blok Kat:1, Mustafa Kemal Cd., 34865 Istanbul, Turkey

Binnaz Kiran, Mersin University, Faculty of Education, Ciftlikkoy, Mersin Unv., 33110 Mersin, Turkey

\section{Suggested Citation:}

Yilmaz, G. G. \& Kiran, B. (2020). Examination of toy preferences - play skills and aggression tendencies of 60-72month-old children. New Trends and Issues Proceedings on Humanities and Social Sciences. 7(3), pp 252261.Available from: www.prosoc.eu

Received from August 24, 2020; revised from September 14, 2020; accepted from November 12, 2020.

Selection and peer review under responsibility of Prof. Dr. Husey in Uzunboylu, Higher Education Planning, Supervision, Accreditation and Coordination Board, Cyprus.

${ }^{\circ} 2020$ BirlesikDunyaYenilikArastirmaveYayincilikMerkezi. All rights reserved.

\begin{abstract}
The purpose of this research is the examination of toy preferences and play skills of 60-72-month-old children according to aggression tendencies. The study group of this research includes 307 people consisting of 60-72-month-old children continuing their kindergarten in Cukurova district of Adana and their parents. As data collection tools, 'Personal Information Form', 'Informed Consent Form' and 'Toy Preference Form' were prepared by the researchers to learn the toy preferences of the children after reviewing the relevant thesis. The 'Aggression Tendency Scale' and 'Play Skill Scale' were used. In accordance with the studies carried out, it is seen that the play skills of the participants differ according to the aggression tendency levels in all sub-dimensions of the aggression tendency scale and there is a negative interrelation. In addition to this, it is seen that the most preferred toys among the children with a high aggression tendency level in all sub-dimensions of the aggression tendency scale are the war toys. It is suggested to make attempts for the determination of the variables effective on the aggression tendency levels and play skills, realisation of more scientific researches regarding the issue of aggression that might have devastating results in social terms and the development of the play skills of the experts working with the children.
\end{abstract}

Keywords: Toy preference, play skill, aggression tendency.

\footnotetext{
* ADDRESS FOR CORRESPONDENCE: Binnaz Kiran, Mersin University, Faculty of Education, Ciftlikkoy, Mersin Unv., 33110 Mersin, Turkey.

E-mail address: binkiran2009@gmail.com
} 


\section{Introduction}

Unlike adults, children use play and toys as well as language for communication. The play can be defined as the activity that the child enjoys to participate in, which has an impact on all areas of development, including the child's cognitive, emotional, physical and social development (Kocyigit, Tugluk \& Kok, 2007). According to educators, the first years of an individual's life are considered important. In this period, called the critical period, adaptation for the child and getting to know the outside world begin with the play (Kaytez \& Durualp, 2014).

The tool used during the play activity can be defined as a toy. When the toy is presented in accordance with the age and development period of the child, it can be defined as a play object that serves many purposes, such as fun, learning, spending time, socialising, and can appear in many different forms. Apart from communicating, they use toys to reflect their feelings, cope with their problems and relax emotionally. Toys suitable for the age and development level of the child are thought to be effective in stimulating the senses, supporting muscle development, increasing the ability to dream, communication capacity and problem-solving ability (Bolisik, Yilmaz, Yavuz \& Buyuk, 2014).

With the development of technology, changes in children's play and toy preferences are also observed. With the widespread use of mass media and the ease of accessibility of these tools, children are also more frequently exposed to mass media and aggressive items transferred from the media. Children can reflect the behaviours they observe in their plays and daily lives by internalising the heroes/characters they see or by establishing identification. These heroes and the audio visual elements exposed can reveal the tendency of aggression in children.

Although there are very different explanations and definitions about aggression, almost all of these views on the subject accept that the aggression impulse is an impulse that the individual cannot ignore or escape. If this impulse cannot be accurately revealed or controlled, it can cause very destructive emotions and behaviours for the individual and for the environment. However, aggression should not be considered as an impulse that should definitely be suppressed and uncovered in terms of protecting, defending and preventing injustices and obstacles (Gultekin, 2008). If people cannot properly reveal this impulse in them, an aggressive energy accumulates, looking for a way to go out. As the aggression turns into a behaviour, the individual can relax and a decrease in the level of aggressive energy is observed (Kagitcibasi, 1999).

Aggressive behaviour is common among adolescents and adults, as well as among children (Gultekin, 2008). Cognitive structures in childhood, which are very open to learning and imitating, play an important role in keeping the clues about aggressive behaviour easy and by gaining continuity of these behaviours. At the same time, childhood is a very important period in eliminating unwanted behaviour or reinforcing the unwanted behaviour (Gultekin, 2008).

Although it exists in every segment of the society and in every period, especially in recent years, the impact and destructiveness, of which is the subject of further research, while being aggressive is a motivation for examining aggression in early childhood; the aim of this study is to examine the toy preference, play skill and aggression tendency that are thought to be related to aggression. When the literature was examined, it was seen that there was a relationship between play skills and toy preferences; the characteristics of this relationship with many different variables, such as gender, age, education level of the mother and father, and depression level of the mother, were examined. However, the relationship between toy preference and play skill according to the aggression tendency has been examined as a new variable which is thought to contribute to the studies in this field.

\section{Material and Method}

This study is a descriptive study in the 'relational screening model', which aims to determine the current situation regarding the relationship between play skill and toy preference according to the 
aggression tendencies of 60-72-month-old children. The universe of the research consists of kindergartens operating in a province in the Mediterranean region. The sample consists of 60-72month-old children, who are attending kindergarten, with a total of 307 people including their parents, determined by the random sampling method. In the study, 'Personal Information Form' and 'Informed Consent Form', created by the researchers, were used as data collection tools as a result of scanning the relevant literature. The '36-72-month-old Aggressiveness Tendency Scale for Children' was used in order to determine to what or to whom the children directed their aggression. In order to measure the play skills of 60-72-month-old children, 'Play Skills Evaluation Scale' and 'Toy Preference Form' and illustrated cards prepared by the researchers to determine the toy choices of 60-72-monthold children were used.

\subsection{Aggressiveness Tendency Scale for 36-72-month-old children}

The scale developed by Kaynak, Kan and Kurtulmus (2016) is a 7-point Likert-type measurement tool. The scale applied on 337 children ( $n=164$ girls; $n=173$ boys) with an average age of 5.3 years in Ankara, Antalya, Hatay, Konya and Mus in the fall semester of the 2014-2015 academic year consisted of 27 items and foursub-dimensions. These dimensions can be listed as 'physical aggression towards others', 'relational aggression towards others', 'aggression towards self' and 'aggression towards items/objects'. The Cronbach's Alpha internal consistency coefficient was determined as 0.957 for the entire scale, whereas it was determined as $0.946,0.945,0.853$ and 0.920 for the sub-dimensions, respectively. All these findings revealed that the scale developed was a valid and reliable measurement tool in determining to what or to whom the 36-72-month-old children directed their aggressions.

\subsection{Play Skills Evaluation Scale}

It is a 5-point Likert-type measurement tool developed by Fazlioglu, Ilgaz and Papatga (2013). It was applied to the parents of 243 children between the ages of 60 and 72 months who were studying in kindergarten in the province of Edirne in the 2011-2012 academic year. As a result of the AFA, a scale consisting of one dimension explaining $36.16 \%$ of the total variance was obtained. CFA was carried out to test the one-dimensional structure. The results showed a satisfactory fit for the model. The standardised regression coefficients of the one-dimensional play skills scale ranged from 0.42 to 0.75 and were statistically significant. Cronbach's alpha value of internal consistency reliability analysis was 0.93 and it was determined to be at a high level.

The analysis of the data was carried out by calculating the statistics regarding the distributions of each scale used in the research and is presented in tables. In the study, the total scores of the subdimensions (physical, relational, towards self and towards things) of the aggression tendency scale were converted into standard scores. Then, a relative valuation method was used (Erkus, 2014), and standard scores above $-1 / 2$ were determined as low, $\pm 1 / 2$ were determined as medium and above $+1 / 2$ were determined as high.

In the study, one-way analysis of variance was envisaged to determine whether the play skills differ according to the sub-scales of aggression, and in this context, it was examined whether the assumptions (normality, homogeneity, etc.) of the variance analysis were met. In the examination of normality, the coefficients of kurtosis and skewness were included in the \pm 2 range of their standard errors (Tabachbick \& Fidell, 2013) and the significance value obtained as a result of normality tests did not differ from the normal distribution of the universe. As a result of the calculations obtained, it was seen that the distribution of the play skill scale scores was not suitable for the normal distribution. The Kruskal-Wallis test, which is the non-parametric equivalent of the one-way analysis of variance, was used. In the research, two-way chi-squared test was used to examine the difference between two independent categorical variables (Buyukozturk, 2018) in order to examine whether children's toy 
preferences differed according to the aggression tendency sub-scales. The condition that $20 \%$ of the expected values in each cell that is not below 5 is considered.

\section{Findings}

Descriptive statistics related to the distribution of the participants' scores on aggression tendency and play skills scales are presented in Table 1.

Table 1. Descriptive statistics on the distribution of points scored by the participants on aggression tendency and play skills evaluation scales

\begin{tabular}{|c|c|c|c|c|c|c|}
\hline & & Play skill & $\begin{array}{l}\text { Physical } \\
\text { aggression }\end{array}$ & $\begin{array}{l}\text { Relational } \\
\text { aggression }\end{array}$ & $\begin{array}{l}\text { Aggression } \\
\text { towards self }\end{array}$ & $\begin{array}{c}\text { Aggression } \\
\text { towards items }\end{array}$ \\
\hline$n$ & & 307 & 307 & 307 & 307 & 307 \\
\hline Average & & 109.2313 & 15.7134 & 13.0326 & 8.1401 & 13.9674 \\
\hline Median & & 110.0000 & 14.0000 & 12.0000 & 6.0000 & 13.0000 \\
\hline Mode & & 120.00 & 8.00 & 7.00 & 5.00 & 7.00 \\
\hline $\begin{array}{l}\text { Standard } \\
\text { Deviation }\end{array}$ & & 13.01163 & 6.67567 & 5.75924 & 4.24994 & 5.69361 \\
\hline Variance & & 169.303 & 44.565 & 33.169 & 18.062 & 32.417 \\
\hline Distortion & & -0.769 & 1.089 & 1.513 & 1.879 & 1.075 \\
\hline $\begin{array}{l}\text { Distortion Std. } \\
\text { Error }\end{array}$ & & 0.139 & 0.139 & 0.139 & 0.139 & 0.139 \\
\hline Flatness & & 0.963 & 1.149 & 3.095 & 4.220 & 1.816 \\
\hline Flatness Std. Error & & 0.277 & 0.277 & 0.277 & 0.277 & 0.277 \\
\hline Change Interval & & 78.00 & 34.00 & 30.00 & 24.00 & 36.00 \\
\hline Lowest Score & & 57.00 & 8.00 & 7.00 & 5.00 & 7.00 \\
\hline Highest Score & & 135.00 & 42.00 & 37.00 & 29.00 & 43.00 \\
\hline $\begin{array}{l}\text { Kolmogorov } \\
\text { Smirnov }\end{array}$ & & 0.068 & 0.138 & 0.147 & 0.230 & 0.115 \\
\hline & $\begin{array}{l}\mathrm{SD} \\
p\end{array}$ & $\begin{array}{c}307 \\
0.001\end{array}$ & $\begin{array}{c}307 \\
0.000\end{array}$ & $\begin{array}{c}307 \\
0.000\end{array}$ & $\begin{array}{c}307 \\
0.000\end{array}$ & $\begin{array}{c}307 \\
0.000\end{array}$ \\
\hline Cronbach's $\alpha$ & & 0.915 & 0.888 & 0.889 & 0.908 & 0.860 \\
\hline
\end{tabular}

When Table 1 is examined, it can be seen that the data are not distributed normally. The findings regarding the Kruskal-Wallis test, which is calculated regarding the differences between the play skills scores according to the participants' physical aggression levels, are presented in Table 2.

Table 2. Kruskal-Wallis test findings regarding examination of play skill points according to physical aggression level

\begin{tabular}{clcccccc}
\hline \multirow{2}{*}{ Variable } & Level & $\overline{\boldsymbol{x}}$ & Median & $\begin{array}{c}\text { Mean } \\
\text { Rank }\end{array}$ & \multirow{2}{*}{$\chi^{2}$} & $\boldsymbol{p}$ & \multicolumn{1}{c}{ Difference } \\
\hline \multirow{3}{*}{ Physical aggression tendency } & Low & 114.6 & 114 & 187.1 & & & Low $>$ Medium \\
& Medium & 109.42 & 112 & 153.81 & 39.352 & 0.000 & Medium $>$ High \\
& High & 101.03 & 103.5 & 105.46 & & Low $>$ High \\
\hline
\end{tabular}

When Table 2 is examined, it can be seen that the play skill scores of the participants differ according to their physical aggression orientation levels $\left(\chi^{2}=39.352, p<0.001\right)$. The Mann-Whitney $\mathrm{U}$ test was used to calculate which group or groups these differences were among, and since there are three comparisons, Bonferroni's correction was applied to prevent error I type (Armstrong, 2014) and the level of significance was determined as $0.016(0.05 / 3=0.016)$. The findings show that participants with a low level of physical aggression tendency have significantly higher play skill scores than participants with medium and high levels, and medium participants with higher levels $(p<0.016)$. 
The findings of the two-way chi-squared test calculated regarding the differences between toy preferences according to the physical aggression levels of the participants are presented in Table 3.

Table 3. Two-way chi-squared test findings regarding examination of toy preferences according to the physical aggression level

\begin{tabular}{lccccccccccc}
\hline \multicolumn{2}{c}{ Aggression tendency } & Baby & Miniature & Hero & War & Artistic/sportive & $\begin{array}{c}\text { Educational/ } \\
\text { manipulative }\end{array}$ & Electronic & Handwork & Total \\
\hline \multirow{3}{*}{ Low } & $n$ & 17 & 12 & 39 & 10 & 6 & 5 & 6 & 20 & 115 \\
Physical & $\%$ & 14.8 & 10.4 & 33.9 & 8.7 & 5.2 & 4.3 & 5.2 & 17.4 & 100 \\
aggression & Medium & $n$ & 6 & 8 & 22 & 21 & 8 & 7 & 27 & 15 & 114 \\
tendency & $\%$ & 5.3 & 7.0 & 19.3 & 18.4 & 7.0 & 6.1 & 23.7 & $13.2 \%$ & 100 \\
& $n$ & $n$ & 3 & 1 & 7 & 39 & 1 & 5 & 14 & 8 & 78 \\
& High & $\%$ & 3.8 & 1.3 & 9.0 & 50.0 & 1.3 & 6.4 & 17.9 & $10.3 \%$ & 100 \\
Total & $n$ & 26 & 21 & 68 & 70 & 15 & 17 & 47 & 43 & 307 \\
& & $\%$ & 8.5 & 6.8 & 22.1 & 22.8 & 4.9 & 5.5 & 15.3 & $14.0 \%$ & 100 \\
\hline
\end{tabular}

$\chi^{2}(14)=83.127, p<0.001$

In the examination of toy preferences according to physical aggression tendency levels, $8.3 \%$ of the expected values in each cell were found to be below 5 , and the procedures continued. When Table 3 is examined, it can be seen that the toys most preferred by children with low physical aggression tendency are toys related to heroism and the least preferred toys are educational/manipulative toys. It can be said that medium-level ones tend to prefer electronic toys more and stayed away from baby toys. It is among the information in the table that the most preferred toys in children with high physical aggression tendency consists of war toys, and the least preferred are miniature toys and artistic/sportive toys. It has been found that these differences observed for different toy preferences of children with different levels of physical aggression are significant $\left(\chi^{2}(14)=83.127, p<0.001\right)$.

The findings regarding the Kruskal-Wallis test, which is calculated regarding the differences between the play skills scores according to the relational aggression levels of the participants, are presented in Table 4.

Table 4. Kruskal-Wallis test findings regarding examination of play skill points according to the relational aggression level

\begin{tabular}{llcccccc}
\hline \multirow{2}{*}{ Variable } & Level & $\overline{\boldsymbol{x}}$ & Median & $\begin{array}{c}\text { Mean } \\
\text { Rank }\end{array}$ & $\chi^{2}$ & $\boldsymbol{p}$ & Difference \\
& Low & 114.82 & 114 & 188.8 & & & Low $>$ Medium \\
Relational aggression & Medium & 109.8 & 111 & 153.72 & 45.107 & 0.000 & Medium $>$ High \\
& High & 100.3 & 102 & 103.42 & & & Low $>$ High \\
\hline
\end{tabular}

When Table 4 is examined, it can be seen that the participants' play skills scores differ according to their relational aggression tendency levels $\left(\chi^{2}=45.107, p<0.001\right)$. The Mann-Whitney $U$ test was used to calculate which group or groups these differences were from, and since there are three comparisons, Bonferroni's correction was applied to prevent error of type I (Armstrong, 2014) and the level of significance was determined as $0.016(0.05 / 3=0.016)$. The findings show that participants with a low level of relational aggression tendency have significantly higher play skill scores than participants with medium and high levels, and medium-level participants with high-level participants $(p<0.016)$. Findings related to the bidirectional chi-squared test calculated regarding the differences between toy preferences according to the relational aggression levels of the participants are presented in Table 5. 
Table 5. Two-way chi-squared test findings regarding examination of toy preferences according to the relational aggression level

\begin{tabular}{|c|c|c|c|c|c|c|c|c|c|c|c|}
\hline \multicolumn{3}{|c|}{ Aggression Tendency } & \multirow{2}{*}{$\begin{array}{c}\text { Baby } \\
15\end{array}$} & \multirow{2}{*}{$\begin{array}{c}\text { Miniature } \\
12\end{array}$} & \multirow{2}{*}{$\begin{array}{c}\text { Hero } \\
36\end{array}$} & \multirow{2}{*}{$\frac{\text { War }}{13}$} & \multirow{2}{*}{$\begin{array}{c}\begin{array}{c}\text { Artistic/ } \\
\text { sportive }\end{array} \\
6\end{array}$} & \multirow{2}{*}{$\begin{array}{l}\text { Educational/ } \\
\text { manipulative }\end{array}$} & \multirow{2}{*}{$\begin{array}{c}\text { Electronic } \\
11\end{array}$} & \multirow{2}{*}{$\begin{array}{c}\text { Handwork } \\
21\end{array}$} & \multirow{2}{*}{$\begin{array}{c}\text { Total } \\
115\end{array}$} \\
\hline & Iom & $n$ & & & & & & & & & \\
\hline & Low & $\%$ & 12.5 & 10 & 30.0 & 10.8 & 5 & 5 & 9.2 & 17.5 & 100 \\
\hline \multirow{4}{*}{$\begin{array}{l}\text { Relational } \\
\text { aggression }\end{array}$} & AMdium & $n$ & 9 & 7 & 23 & 21 & 8 & 5 & 18 & 14 & 114 \\
\hline & Tvecirum & $\%$ & 8.6 & 6.7 & 21.9 & 20.0 & 7.6 & 4.8 & 17.1 & 13.3 & 100 \\
\hline & Hirh & $n$ & 2 & 2 & 9 & 36 & 1 & 6 & 18 & 8 & 78 \\
\hline & rign & $\%$ & 2.4 & 2.4 & 11.0 & 43.9 & 1.2 & 7.3 & 22.0 & 9.8 & 100 \\
\hline \multirow{2}{*}{ Total } & & $n$ & 26 & 26 & 21 & 68 & 70 & 15 & 17 & 47 & 43 \\
\hline & & $\%$ & 8.5 & 8.5 & 6.8 & 22.1 & 22.8 & 4.9 & 5.5 & 15.3 & 14 \\
\hline
\end{tabular}

$\chi^{2}(14)=53.977, p<0.001$.

In the examination of toy preferences according to the relational aggression tendency levels, it was observed that $4.01 \%$ of the expected values in each cell were below 5 , and the processes continued. When Table 5 is examined, it can be seen that the toys most preferred by children with low relational aggression tendency are toys related to heroism, and the least preferred toys are educational/manipulative and artistic/sportive toys. It can be said that the medium-level ones tend to be more towards heroic toys and stayed away from educational/manipulative toys. It is among the information in the table that the most preferred toy in children with high relational aggression tendency consists of war toys, and the least preferred are artistic/sportive toys. It has been found that these observed differences regarding different toy preferences of children with different levels of relational aggression tendency are significant $\left(\chi^{2}(14)=53.977, p<0.001\right)$.

The findings regarding the Kruskal-Wallis test, which is calculated regarding the differences between the play skills scores of the participants according to their aggression levels, are presented in Table 6.

Table 6. Kruskal-Wallis test findings regarding examination of play skill points according to the aggression towards self level

\begin{tabular}{llcccccc}
\hline Variable & Level & $\overline{\boldsymbol{x}}$ & Median & Mean rank & $\boldsymbol{X}^{\mathbf{2}}$ & $\boldsymbol{p}$ & Difference \\
\hline \multirow{3}{*}{ Aggression towards self } & Low & 111.74 & 111 & 165.87 & & & \\
& Middle & 109.27 & 111 & 154.31 & 6.656 & 0.036 & \\
& High & 104.53 & 109 & 131.63 & & & Low $>$ High \\
\hline
\end{tabular}

When Table 6 is examined, it can be seen that the participants' play skills scores differ according to their aggression tendency levels $\left(\chi^{2}=6.656, p<0.05\right)$. The Mann-Whitney $U$ test was used to calculate which group or groups these differences were from, and since there are three comparisons, Bonferroni's correction was applied to prevent error of type I (Armstrong, 2014) and the level of significance was determined as $0.016(0.05 / 3=0.016)$. The findings show that participants with a low level of aggression towards themselves have significantly higher play skill scores than those with a high level $(p<0.016)$. Findings related to the bidirectional chi-squared test calculated regarding the differences between toy preferences according to the participants' aggression levels are presented in Table 7. 
Table 7. Two-way chi-square test findings related to examination of toy preferences according to the aggression level towards self

\begin{tabular}{|c|c|c|c|c|c|c|c|c|c|c|c|}
\hline Aggression & Tendency & & Baby & Miniature & Hero & War & $\begin{array}{l}\text { Artistic/ } \\
\text { sportive }\end{array}$ & $\begin{array}{l}\text { Educational/ } \\
\text { manipulative }\end{array}$ & Electronic & $\begin{array}{l}\text { Hand } \\
\text { Work }\end{array}$ & Total \\
\hline \multirow{6}{*}{$\begin{array}{l}\text { Aggression } \\
\text { towards } \\
\text { self }\end{array}$} & \multirow{2}{*}{ Low } & $n$ & 14 & 11 & 32 & 16 & 10 & 9 & 14 & 21 & 127 \\
\hline & & $\%$ & 11 & 8.7 & 25.2 & 12.6 & 7.9 & 7.1 & 11.0 & 16.5 & 100 \\
\hline & \multirow{2}{*}{ Medium } & $n$ & 9 & 8 & 27 & 28 & 5 & 4 & 20 & 10 & 111 \\
\hline & & $\%$ & 8.1 & 7.2 & 24.3 & 25.2 & 4.5 & 3.6 & 18 & 9 & 100 \\
\hline & \multirow{2}{*}{ High } & $n$ & 3 & 2 & 9 & 26 & 0 & 4 & 13 & 12 & 69 \\
\hline & & $\%$ & 4.3 & 2.9 & 13.0 & 37.7 & 0 & 5.8 & 18.8 & 17.4 & 100 \\
\hline \multirow{2}{*}{ Total } & & $n$ & 26 & 26 & 21 & 68 & 70 & 15 & 17 & 47 & 43 \\
\hline & & $\%$ & 8.5 & 8.5 & 6.8 & 22.1 & 22.8 & 4.9 & 5.5 & 15.3 & 14 \\
\hline
\end{tabular}

In the examination of toy preferences according to the levels of aggression towards self, it can be seen that $3 \%$ of the expected values in each cell are below 5 , and the processes continued. When Table 7 is analysed, it can be seen that the toys most preferred by children with a low level of aggression towards themselves are toys related to heroism, and the least preferred toys are educational toys. It can be said that medium-level people inclined more towards war-related toys and stayed away from educational/manipulative toys. It is among the information in the table that children with high aggression towards themselves are similarly preferred war toys and least preferred artistic/sportive toys. These observed differences are regarding the different toy preferences of children with different levels of self-directed aggression. It is among the information in the table that the most preferred toys in children with high aggression towards themselves are similarly made up of war toys and the least preferred are artistic/sportive toys. It has been found that these observed differences regarding the different toy preferences of children with different levels of self-directed aggression are significant $\left(\chi^{2}(14)=33.495, p<0.001\right)$.

The findings regarding the Kruskal-Wallis test, which is calculated regarding the differences between the play skills scores of the participants according to their level of aggression towards items, are presented in Table 8.

Table 8. Kruskal-Wallis test findings regarding examination of play skill points according to the aggression level of items

\begin{tabular}{llcccccc}
\hline \multicolumn{1}{c}{ Variable } & Level & $\overline{\boldsymbol{x}}$ & Median & $\begin{array}{c}\text { Rank } \\
\text { Mean }\end{array}$ & $\chi^{2}$ & $\boldsymbol{p}$ & Difference \\
\hline \multirow{2}{*}{$\begin{array}{l}\text { Aggression Towards } \\
\text { Items }\end{array}$} & Low & 114.52 & 114 & 186.59 & & & Low $>$ Medium \\
& Medium & 109.61 & 113 & 155.65 & 41.233 & 0.000 & Medium $>$ High \\
& High & 101.75 & 105 & 108.6 & & Low $>$ High \\
\hline
\end{tabular}

When Table 8 is analysed, it can be seen that the play skill scores of the participants differ according to their aggression tendency towards items $\left(\chi^{2}=41.233, p<0.001\right)$. The Mann-Whitney $U$ test was used to calculate which group or groups these differences were from, and since there are three comparisons, Bonferroni's correction was applied to prevent error of type I (Armstrong, 2014) and the level of significance was determined as $0.016(0.05 / 3=0.016)$. The findings show that participants with a low level of aggression towards items have significantly higher play skill scores than participants with medium and high levels, and medium participants with higher levels $(p<0.016)$.

The findings regarding the two-way chi-squared test calculated regarding the differences between the toy preferences according to the aggression tendency levels of the participants are presented in Table 9. 
Table 9. Two-way chi-squared test findings related to examination of toy preferences according to aggression level of items

\begin{tabular}{|c|c|c|c|c|c|c|c|c|c|c|c|}
\hline \multicolumn{3}{|c|}{ Aggression tendency } & \multirow{2}{*}{$\begin{array}{c}\text { Baby } \\
13\end{array}$} & \multirow{2}{*}{$\begin{array}{c}\text { Miniature } \\
12\end{array}$} & \multirow{2}{*}{$\begin{array}{c}\text { Hero } \\
42\end{array}$} & \multirow{2}{*}{$\begin{array}{c}\text { War } \\
14\end{array}$} & \multirow{2}{*}{$\begin{array}{c}\text { Artistic/ } \\
\text { sportive }\end{array}$} & \multirow{2}{*}{$\begin{array}{c}\text { Educational/ } \\
\text { manipulative }\end{array}$} & \multirow{2}{*}{$\begin{array}{c}\text { Electronic } \\
9\end{array}$} & \multirow{2}{*}{$\begin{array}{c}\text { Hand work } \\
25\end{array}$} & \multirow{2}{*}{$\begin{array}{r}\text { Total } \\
125\end{array}$} \\
\hline \multirow{6}{*}{$\begin{array}{l}\text { Aggression } \\
\text { towards } \\
\text { items }\end{array}$} & 10 & $n$ & & & & & & & & & \\
\hline & Low & $\%$ & 10.4 & 9.6 & 33.6 & 11.2 & 1.6 & 6.4 & 7.2 & 20 & 100 \\
\hline & \multirow{2}{*}{ Medium } & $n$ & 9 & 7 & 16 & 13 & 11 & 5 & 20 & 8 & 89 \\
\hline & & $\%$ & 10.1 & 7.9 & 18 & 14.6 & 12.4 & 5.6 & 22.5 & 9 & 100 \\
\hline & \multirow{2}{*}{ High } & $n$ & 4 & 2 & 10 & 43 & 2 & 4 & 18 & 10 & 93 \\
\hline & & $\%$ & 4.3 & 2.2 & 10.8 & 46.2 & 2.2 & 4.3 & 19.4 & 10.8 & 100 \\
\hline \multirow{2}{*}{ Total } & & $n$ & 26 & 26 & 21 & 68 & 70 & 15 & 17 & 47 & 43 \\
\hline & & $\%$ & 8.5 & 8.5 & 6.8 & 22.1 & 22.8 & 4.9 & 5.5 & 15.3 & 14 \\
\hline
\end{tabular}

$\chi^{2}(14)=82.853, p<0.001$.

In the examination of toy preferences according to the aggression tendency levels for items, it was observed that $4.35 \%$ of the expected values in each cell were below 5 , and the processes continued. When Table 9 is examined, it can be seen that the toys that are most preferred by children with low aggression tendency towards items are toys related to heroism, and the toys they choose least are artistic/sportive toys. It can be said that medium-level ones inclined to focus more on electronic toys and stayed away from educational/manipulative toys. It is among the information in the table that the most preferred toys in children with high aggression towards items are war toys, and the least preferred are artistic/sportive and miniature toys. It has been found that these observed differences regarding different toy preferences of children with aggression tendency levels for different items are significant.

\section{Discussion, Conclusion and Suggestions}

It was found that there is a negative relationship between the aggression tendency and play skill in all sub-dimensions of aggression tendency. When the literature is analysed, there are studies that overlap with our inference and study findings that children with high play skills will have high social adaptation and physical aggression will be low (Cirhinlioglu,2015; Ozcan,2018). In addition to the therapeutic power of the play, Schaefer (2013) addresses the importance of functions that affect the play skill, such as coping with stress, raising the ego and helping develop relationships. This information seems to be related to the insufficiency of children with low play skills in developing relationships and expressing themselves with high relational aggression. According to Spencer, the play is an activity that reduces tension. According to Groos, the leading name in life preparation theory, the play is an activity that relieves tension and the way out of the primitive tendencies in the child. In other words, it is accepted that aggression can be eliminated through the play (Yavuzer, 2015). The high aggressiveness of children with low play skills is supported by the suggestions of these theories.

According to the other findings of our study, in the sub-dimensions of the aggression tendency scale, the toys most preferred by children with high aggression tendency level are war toys and the least preferred ones are artistic/sportive and miniature toys. Adler, one of the advocates of psychoanalysis, one of the many theories that explains aggression, argues that aggression is caused by the motivation to meet one's needs and is a neurotic protector (Karakulak, 2018). One of the toys preferred by children with a high level of physical aggression tendency can be interpreted as the motivation to meet the need of the child in need of power or defence according to Adler's theory. According to Freud, the selection of such toys can be interpreted as a result of the innate aggressive impulse (Karakulak, 2018). In Gestalt's play therapy, the therapist uses some techniques in which art is 
effective, such as creative drama, story, drawing, use of metaphor and sand therapy in order to express the child's suppressed emotion in a healthy way (Schaefer, 2013).

It shows that the toys that are the least preferred by children with high relational aggression tendency are artistic/sportive toys, which is in line with the view that the child who does not turn his/her anger into healthy actions can act aggressively. Jung makes drawing transitions at the end of his therapy with children, i.e., it is supportive for the child's aggression in a healthy way. This perspective supports the view that artistic toys or actions will reduce the child's urge to aggression (Green, 2016). As a result of the study of Selimen (2016), it was concluded that the computer play involving violence had a significant effect on the tendency to show aggression behaviour for each of the dimensions of aggression in children. This finding is consistent with the relationship of the toys of choice for children with high aggression towards self, which are the results of our study.

Considering the approaches of play therapy theories about aggression, the techniques of analytical play therapy such as drawing and sand therapy are used for reducing aggression (Green, 2016); Adleri an play therapy uses puppets and art materials (Schaefer, 2013); the techniques of Gestalt's therapy use story-telling, drawing, use of metaphor and sand therapy (Schaefer, 2013). It is known that cognitive play therapy uses art materials such as paper, paint, brush, etc. as it is an art to reflect emotions and thoughts (Cavett, 2017). The fact that different theoretical approaches use artistic techniques to reduce aggression and the fact that children with a high aggression tendency in our research findings do not prefer artistic toys are among the overlapping information.

When we evaluate the findings of our study, in which the aggression tendency, toy preference and play skills of 60-72-month-old children were examined, the following results are obtained:

- In all sub-dimensions of aggression tendency (physical aggression, relational aggression, aggression towards items and self), there is a negative relationship between the level of aggression tendency and play skill.

- It is among the findings that the most preferred toys in children with high physical aggression tendency are war toys (50\%) and the least preferred are miniature toys and artistic/sportive toys (1.3\%).

- It is among the findings that in children with high relational aggression tendency, the most preferred toy are war toys (43.9\%) and the least preferred are artistic/sportive toys (1.2\%).

- It is among the findings that in children with high aggression towards self, similarly the most preferred toys are war toys (37.7\%) and the least preferred are artistic/sportive toys $(0 \%)$.

- It is among the findings that in children with high aggression towards items, the most preferred toys are war toys (46.2\%) and the least preferred are artistic/sportive and miniature toys (2.2\%).

In light of the findings obtained from the research, the following suggestions can be made:

1. It is recommended that specialists working with children (psychological counsellors, psychologists, social workers, etc.) organise activities that develop play skills for the family and other teachers on the importance of play for the child's mental health and development.

2. It is also thought that the studies carried out on whether children's toy preferences, playing skills and aggression tendency levels are related to whether or not to attend preschool education institutions, their relationship with the socio-economic situation and attachment styles will contribute to the academic world.

3. In this study, a more general result of the collection of data from Turkey is recommended. 


\section{References}

Armstrong, R. A. (2014). When to use the Bonferroni correction. Ophthalmic and Physiological Optics, 34, 502508. doi:10.1111/opo.1213

Bolisik, B., Yilmaz, B. H., Yavuz, B. \& Buyuk, T. E. (2014). Yetiskinlerincocuklaricinoyuncakseciminey one likdavranislarinincelenmesi. Gumushane Universitesi Saglik Bilimleri Dergisi, 3(4), 976-990.

Buyukozturk, S. (2018). Sosyalbilimlericinverianalizi el kitabi. Ankara, Turkey: Pegem.

Cavett, A. M. (2017). Oyunterapisikapsamliteoriveuygulamarehberi. (D. N. Biyikli \& B. Tuncel, Cev.) Istanbul, Turkey: Apamer Psikoloji Yayinlari.

Cirhinlioglu, F. G. (2015). Cocukgelisimiveruhsagligi (3.Baski). Ankara, Turkey: Nobel.

Erkus, A. (2014). Davranisbilimleriicinbilimselarastirmasureci. Ankara, Turkey: Seckin.

Fazlioglu, Y., Ilgaz, G. \& Papatga, E. (2013). Oyunbecerileridegerlendirmeolcegigecerlikguvenirlikcalismasi. Trakya Universitesi Sosyal Bilimler Dergisi, 15(1): 239-250.

Green, E. J. (2016). CocukveergenlerleJungcuoyunterapisi el kitabi. Istanbul, Turkey: Nobel Yasam.

Gultekin, F. (2008). Saldirganlikve of keyiazaltma programininilkogretimikincikademeogrencilerininsaldirga nlikve of keduzeyleriuzerindekietkisi. Ankara, Turkey: DoktoraTezi, Hacettepe Universitesi Sosyal Bilimler Enstitusu.

Kagitcibasi, C. (1999). Yeni insanveinsanlar. Istanbul, Turkey: Evrim Yayinevi.

Karakulak, F. (2018). Cocuklukdonemindeailelcisiddetemaruzkalanergenlerdesaldirganlikegilimi. Istanbul, Turkey: Yuksek Lisans Tezi, Istanbul Gelisim Universitesi Sosyal Bilimler Enstitusu.

Kaynak, B., Kan, A., \& Kurtulmus, Z.(2016). 36-72 Aylikcocuklaray one lik 'SaldirganlikY onelimOlcegi' gelistirmecalismasi. Turkish studies- international periodical for the languages, literature and history of Turkish or Turkic, 11(3), 1457-1474. doi:10.7827/TurkishStudies.9385

Kaytez, N. \& Durualp, E. (2014). Turkiye'deokuloncesindeoyunileilgiliyapilanlisansustutezlerinincelenmesi. Uluslararasi Turk Egitim Bilimleri Dergisi, 2,111.

Kocyigit, S., TuglukM. \& Kok, M. (2007). Cocugungelisimsurecindeegitselbiretkinlikolarakoyun. Ataturk Universitesi Kazim Karabekir Egitim Fakultesi Dergisi, 16, 324-342.

Ozcan, O. (2018). Cocuklardasosyaluyumveuyumsuzlugunyordayicilari: saldirganlikveebeveynofkesi. Burdur, Turkey: Yuksek Lisans Tezi, Mehmet Akif Ersoy Universitesi Egitim Bilimleri Enstitusu.

Schaefer, C. E. (2013). Oyunterapisinintemelleri (2. Baski). Banu Tortamis Ozkaya (Cev.). Ankara, Turkey: Nobel.

Selimen, M. (2016). Siddeticerenbilgisayaroyunlarinin 13-14 yasgrubucocuklarinsaldirganlikdavranisiuzerinde kietkileri: Yalovaornegi. Yalova, Turkey: Yuksek Lisans Tezi, Yalova Universitesi Sosyal Bilimler Enstitusu.

Tabachbick, B. G. \& Fidell, L. S. (2013). Using multivariate statistics (6th ed.). London, UK: Pearson Education.

Yavuzer, H. (2015). Cocukpsikolojisi (p. 38). Istanbul, Turkey: Remzi. 